\title{
THE INCREASING OF OLIVE RIDLEY (Lepidochelys olivacea) POPULATION AND ITS CORRELATION WITH CONSERVATION ACTIVITY IN ALAS PURWO NATIONAL PARK BANYUWANGI-EAST JAVA
}

\author{
Priyo Suharsono Sulaiman and Ngurah Nyoman Wiadnyana \\ Researcher at Research Centre for Capture Fisheries, Ancol-Jakarta \\ Received September 8-2009; Received in revised form October 19-2009; Accepted October 29-2009
}

\begin{abstract}
One of the sea turtles nesting location in Indonesia that have a positive impact for olive ridley (Lepidochelys olivacea) captivity breeding is National Park Alas Purwo (TNAP) District of Banyuwangi East Java Province. Research was done by observation, interviews and descriptive analysis. This research includes sea turtles captivity breeding activities as conservation efforts and also reviews the conservation success rate of increasing olive ridley population. Captivity breeding process of sea turtles in TNAP are divided into five phases: lalar (search for and collect sea turtle eggs), preparation and making of semi-natural nest, eggs incubation, maintenance and also release tukik (baby of sea turtle). Sea turtles conservation efforts in TNAP showed positive impact for the olive ridley but not yet for the other three species of sea turtles (green turtle, hawksbill and leatherback). Increase trend of olive ridley numbers those nested in TNAP should be used as a success indicator of captivity bieeding and conservation processes those undertaken. Conversely, the presence of green turtles populations and leatherback turtles very low and tends to decline. This condition is expected to push for increasing activity of nesting turtle's habitat conservation in TNAP and also in the other of sea turtles nesting areas.
\end{abstract}

KEYWORDS: $\quad$ captivity breeding, conservation, sea turtle, TNAP

\section{INTRODUCTIONS}

Well management of sea turtle nesting habitat is one of the key factors to maintain the existence of sea turtle populations that decline in the last few decades. In Indonesia there are several turtles nesting sites relatively well managed. One of them is Alas Purwo National Park (TNAP) District of Banyuwangi East Java Province. TNAP has potential coastal areas to support reproductiv 3 process of turtles. According Kurniawan et al. (2003) there are four species of sea turtles nesting in this region, such as olive ridley (Lepidochelys olivacea), leatherback (Dermochelys coriacea), hawksbill (Eretmochelys imbricata), and green turtle (Chelonia mydas).

The TNAP has made great efforts of conservation to increase the sea turtle populations in the region. The activity on sea turtle conservation activity initiated in 1983 with the main action to developing a captive breeding, inventorying the number of sea turtles landed and doing semi-natural hatchery of collected eggs from nesting habitat of TNAP. These efforts likely resulted positive impact for increasing number of olive ridley species, but the presence of the other sea turtles species declines continuously. However, the nesting habitat management of sea turtles needs to maintain and develop, because without good management efforts of this area might give bad effect for sea turtle landing in the nesting habitat
There are several steps to produce hatchlings in conservation area until their releasing to the sea. This paper describes the captivity breeding activities of sea turtle as part of conservation efforts undertaken in TNAP Banyuwangi East Java Province and reviews the success history of sea turtles conservation efforts based on the trend of sea turtles nested in TNAP.

\section{MATERIALS AND METHODS}

\section{Location Description}

TNAP is located in Tegaldlimo and Purwoharjo Sub district, Banyuwangi District-East Java Province. Geographically, TNAP is located in the east cape of Java Island, south beach region between $8^{\circ} 26^{\prime} 45^{\prime \prime}-$ $8^{\circ} 47^{\prime} 00^{\prime \prime}$ South Latitude and $114^{\circ} 20^{\prime} 16^{\prime \prime}-114^{\circ} 36^{\prime} 00^{\prime \prime}$ East Lengthwise. TNAP has 43,420 ha wide, consisting of several zones: a sanctuary zone of 17,200 ha, a wilderness zone of 24,767 ha, an intensive use zone of $250 \mathrm{ha}$, and a buffer zone of $1,203 \mathrm{Ha}$. Generally, TNAP has flat topography, light to heavy wavy with the highest top Lingga Manis Mountain of 332 meters above sea surface level. Almost all of soil conditions are kind of sandy clay soil and small part of its formed light and soft soil. Beside it serve as sea turtle nesting habitat, TNAP area is also appropriate for the habitat of various kinds of animals such as mammals, birds and reptiles (Kurniawan et al., 2003). 


\section{Data Collection}

Field survey was conducted in July 2004 in PancurMarengan Beach TNAP using survey methods (direct observation) and interviews. Data collection was continued in 2008. The data taken is from sea turtle captivity breeding activities and record on the number of nest. Updating data of sea turtle nesting in PancurMarengan Beach TNAP was done until the end of 2008 , to know the trends of sea turtles nesting in TNAP. The data collected were analyzed descriptively.

\section{RESULTS AND DISCUSSION}

\section{Captivity Breeding of Sea Turtles}

The process of captivity and breeding of sea turtle in TNAP divided into 5 (five) phases:

1. Searching and collecting sea turtle eggs that called "Lalar". This activity includes:

a. Walking around the beach at night along the Pancur-Marengan beach of TNAP was started at low tide to look for sea turtles tracks forward up side of the beach until their laying place.

b. Searching the nesting places and identifying the species of sea turtle was done by identifying sea turtle tracks, which are recognized from flipper print on the beach sand. Each species of sea turtle has deferent flipper tracks. Green turtle and leatherback has a parallel flipper track between right and left flipper, while olive ridley and hawksbill has opposite flipper track between right and left flipper (Figure 1).

Generally turtle will land and nest in high tide condition. To begin the nesting process, first sea turtle will dig a hole same with body size using front flipper, then with rear flipper sea turtle will make a hole with a smaller size for the eggs nest. In this laying process cloaca of sea turtle will stretch and pulled out an egg from 1 - 4 eggs at once to a certain amount depending on the species of sea turtles. Once the laying is complete, sea turtle closes its nesting hole using two pairs of rear and front flipper alternately and then compacted. Sometimes sea turtle circling above the nest hole, after that sea turtle will walk toward the side as far about two to three meter to make a false or artificial nest and turtle will return to the sea (Septiastini et al., 2000; Wiadnyana \& Fitriyanto, 2009 in preparation).

c. Excavating nesting hole and eggs retrieval. After finding turtle nest, it started with excavation process, which is done carefully by using hands without tools to avoid the damage of eggs that may occur during the excavation process. Each species of sea turtle has different fecundities but generally, the amount of eggs laid ranges from 70-200 eggs per female. The eggs were taken carefully one by one, placed in bag or plastic bag, and brought to a seminatural incubation. In some cases when the nest position is safe during high tide, sea turtle eggs are not removed from their nest, but left to hatch in its natural place. In this case, a security fence made from bamboo will be install in around the nest hole (Figure 2) to protect sea turtle eggs from predators such as biawak (Saranus salvaator), wild boar (Sus scrofa), albatross (Heliaetus leucogaster), and sea crab (Cerra ceratus) (Kurniawan \& Ponihadi, 2004).

2. Preparation and making a semi-natural nest. Seminatural nest or more often called hatching cages is located in open space and above the highest tide line. Hatching cage is made with clean surface sand and digging sand with the similar depth of natural nest ranging from $35-85 \mathrm{~cm}$ and diameter from $15-25 \mathrm{~cm}$.

3. Eggs Incubation. Sea turtle eggs from one female are incubated in a nest hole that has been prepared. Then the nest hole covered with sand and marked with a small board written starting date incubation, the number of incubated eggs, and name of female
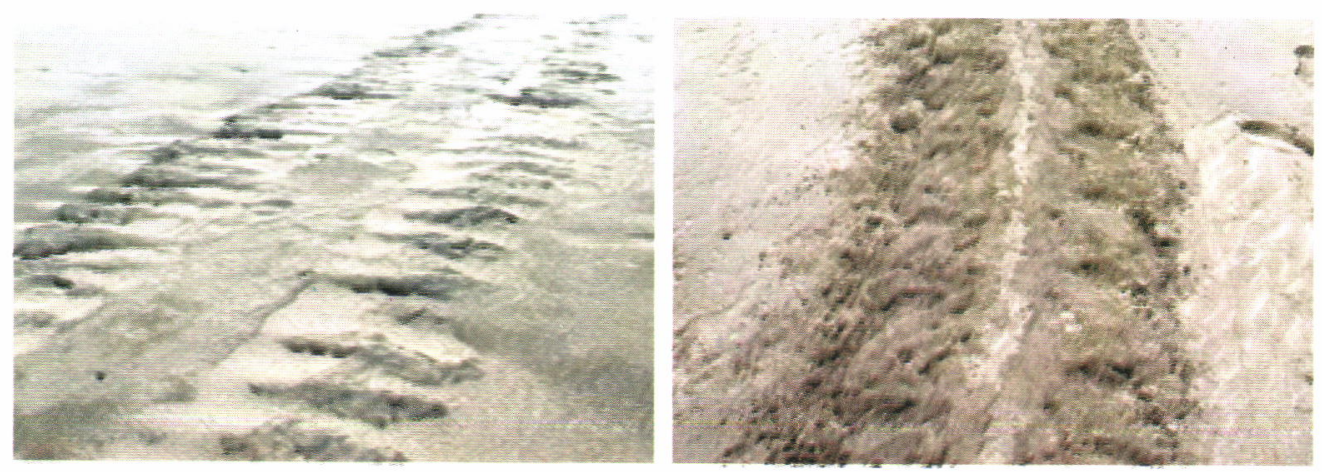

Figure 1.

Flipper track of green turtle (left) and flipper track of olive ridley (right). 
species, and if it is necessary the date of sea turtle nesting (Figure 3).

After 50-60 days of egg incubation, the eggs hatched and some hatchling would come out to the surface of the hole. The number of hatchlings is recorded in order to know the percentage of hatching success. The hatchlings may be maintained in culture tank or be released directly to the sea, depending on the capacity of the culture tank available. Depending on the species, naturally eggs that are incubated naturally may be hatched after 40-72 days (Crite, 2000). This also depends on the natural condition. The eggs nest which exposed to direct sunlight will hatch more quickly than the normal time required (less than 45 days), but the survival rate of hatchlings is low. The penetration of direct sunlight into the sand can rise the sand temperature is too high, resulting the sex of hatchling more female than male. In contrast, under the vegetation, the nest does not receive direct sunlight the eggs need a much longer time of incubation to hatch. After the eggs hatched, hatchlings will come out to surface and crawl towards to the sea. The hatchlings simultaneously charge into the sea at night to start his new life in the water. There are several factors, which affect the discharge of hatchlings to the surface of the sand. One factor is the drop in temperature. Hatchlings would go out to the sand surface at night, when the air temperature is quite cool.

4. Hatchling's culture. Hatchling's culture phase is conducted by using a $10 \mathrm{~L}$ of culture tank. Culture tank is filled with sea water as high as $10-30 \mathrm{~cm}$ adjusted with hatchling age. The number of hatchling kept in a culture tank is adapted to the capacity of culture tank. Each tank is filled with seawater and replaced with new clean waters every morning and afternoon. The hatchlings are feed with chopped sardine twice a day every morning and afternoon.

5. Hatchling release. The hatchlings are released to the sea if they are in healthy condition and strong enough. In general, the hatchling released to the sea, are already three months of old. These hatchlings seem be strong and able to dive, so that the natural mortality rate would be low because the hatchlings might avoid the predators in the sea.

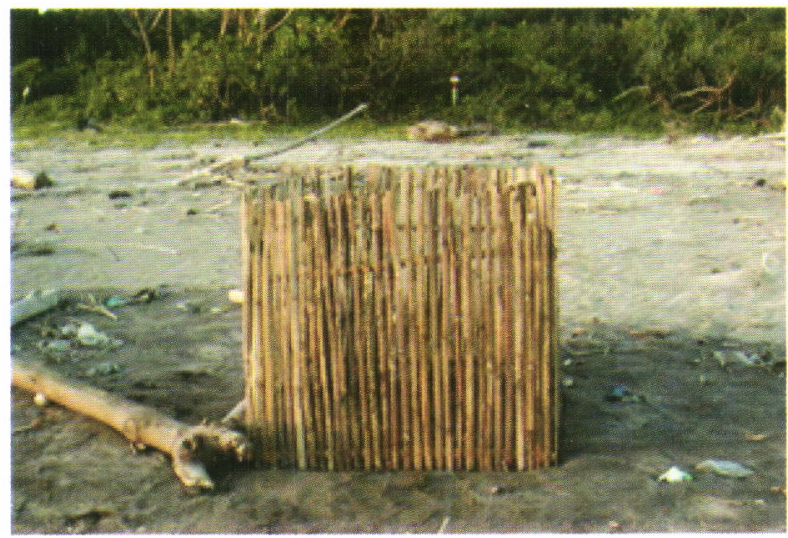

Figure 2. Security bamboo fence for natural nest.

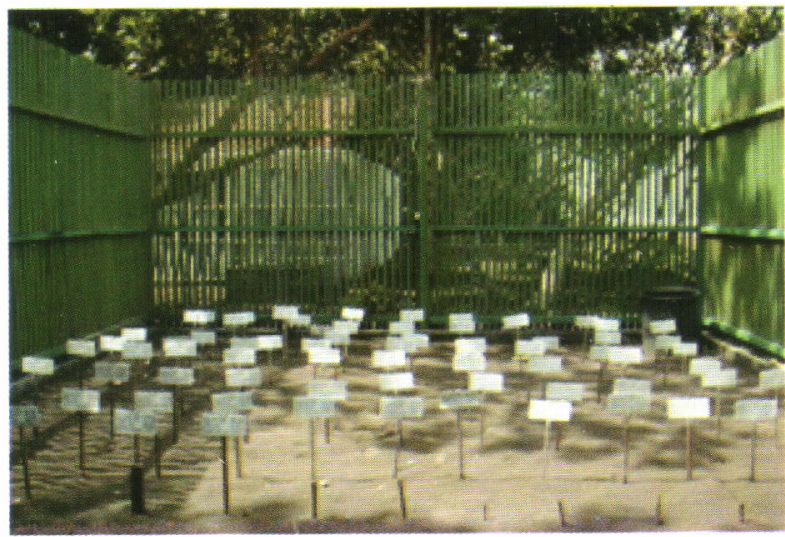

Figure 3. Semi-natural nest (hatchling cage). 


\section{Impact of Sea Turtle Conservation Effort}

Sea turtle conservation effort in TNAP started in 1983 with captivity breeding activity has shown a positive impact for olive ridley, but it has not been yet for the other three species. For more detail, the increase or decrease trend of sea turtle number nested in TNAP can be seen in the Figure 4 and 5 .

The increase trend of sea turtles nesting number in TNAP can be used as one of success indicator made in sea turtles captivity breeding and conservation process. In the TNAP, olive ridley is the easiest species of sea turtle to captive breeding compared with three other species (hawksbill, green turtle, and leatherback). Beside that, olive ridley is also not a sea turtle species of high economic value, because its physically shape is less attractive, and the taste of its meat is unfavorable for the people (Nuitja, 1996).

The hunting of hawksbill species is suspected to cause the low number of hawksbill population nesting in TNAP. The taste of hawksbill's meat is not as good as green turtle meat, but hawksbill has a very beautiful carapace, this may stimulate many people to hunt this species for carapace utilization. Hawksbill's carapace is generally exported to Japan, Hong Kong, South Korea and some countries in Europe as a raw material of handicraft industry.

The presence of green turtle populations and leatherback in TNAP is very low and tends to decline. Figure 5 shows that the declining trend of number of those both sea turtles seems be worry. The decrease of the number might be due to the direct take both green turtle and leatherback as well as their eggs. The meat of green turtle has a high economic value. As know before, green turtle was so far the most hunted turtles by the public, particularly by some people in a Bali for completing their religious ceremony purpose using sea turtle meat for long time ago (Dermawan \& Adnyana, 2003). For Bali's people, sea turtle is sacred animal that can be used for offerings. Adnyana (2004) adds that sea turtle catchers need more long time to capture some number of individual to fulfill sea turtles market in Bali. By decreasing the use of sea turtles in Bali as material consumption recently, green turtle population might be expected to increase, especially that nested in TNAP or other nesting areas.

Leatherback meat is poisonous, so its utilization is limited to leatherback eggs. Based on Figure 5 the
Olive Ridley

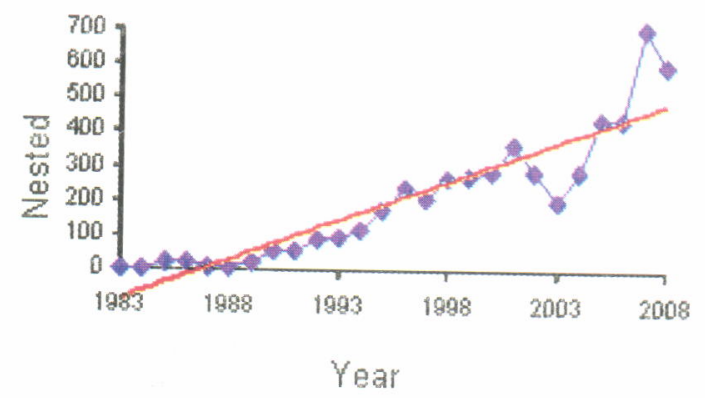

Hawksbill

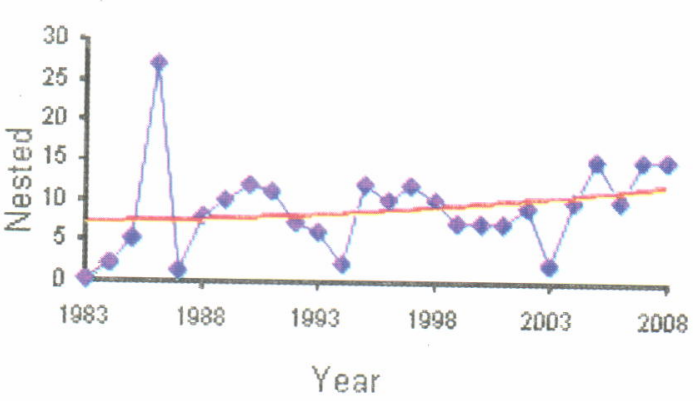

Figure 4. The trend of olive ridley and hawksbill turtle nested in TNAP.

Green Turtle

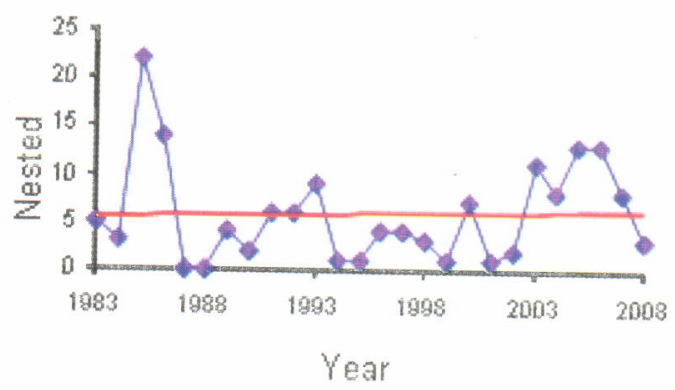

Leatherback

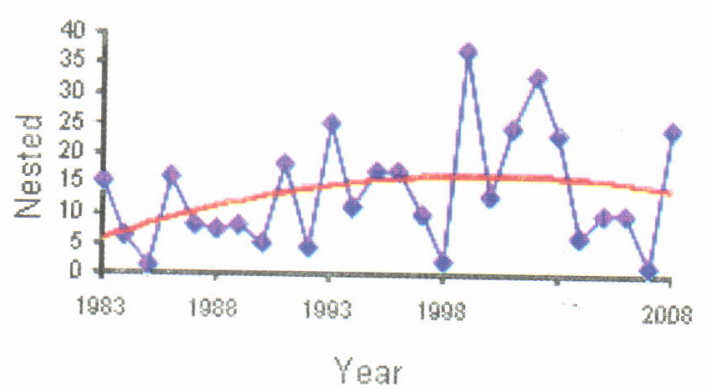

Figure 5. The trend of green turtle and leatherback turtle nested in TNAP. 
number of leatherback, which nests in TNAP is fluctuated with a decreasing trend. This might be correlated with habitat degradation around sea turtle nesting beaches in TNAP, which has an open topography and relatively flat elevation angle that less suitable to support the needs of the leatherback nesting location. Leatherback species likes more a little steep coastal with ranges from 6.69-6.98 degrees (Sulaiman, 2004). A steep beach seems making easier for leatherback to laying eggs in the highest tide line without having to false crawl away to the mainland from the beach. Horrocks \& Scott (1991) state that leatherback selects a good elevation condition for nesting.

\section{CONCLUSIONS}

In term of conservation effort in TNAP, the captivity breeding process of sea turtles is divided into five phases, such as: searching for and collecting sea turtle eggs, preparation, and making of semi-natural nest, egg incubation, maintenance and release hatchling. Sea turtle conservation effort in TNAP shows positive results for olive ridley species, but it is not yet for the other three species (green, hawksbill, and leatherback). The increasing trend of olive ridley which nests in TNAP can be used as an indicator of the success of captivity breeding and conservation effort that undertaken. The presence of green turtle and leatherback populations is very low and tends to decline, so this success effort for olive ridley might be expected to stimulate further efforts to increase conservation activities in TNAP for three other sea turtle species

\section{ACKNOWLEDGMENTS}

This paper is a contribution of research activity on "Sea Turtle Research Conservation". The authors wish to thank the Director of Taman Nasional Alas Purwo who provided the data and information on sea turtle landing. Many thanks are dedicated to Editors of this jurnal.

\section{REFERENCES}

Adnyana, I. B. W. 2004. (in Indonesian). Sea Turtle Ecotourism: The Economical Harmony and Ecology. Presented in Seminar The Development Strengthened of Sea Turtle Ecotourism as Utilization Alternatives of Extractive Sea Turtle. WWF-Indonesia. Denpasar. $26^{\text {th }}-27^{\text {th }}$ February 2004.
Crite, J. 2000. Chelonia mydas (Green Sea Turtle) in T, Dewey (Ed.). Bio 108 section 3: Introduction to Animal Diversity. The Regent of University of Michigan.

Dermawan, A. \& I. B. W. Adnyana. 2003. (in Indonesian). The Sea Turtle Management Guidelines and it's Habitats. Directorate of Conservation and National Marine Park. Ministry of Marine Affairs and Fisheries.

Horrocks, J. A. \& N. M. Scott. 1991. Nest Site Locations and Ness Success in The Hawksbill Turtle (Eretmochelys imbricata) in Barbados. West Indies. Mar. Ecol. Prog. Ser. 69: 1-8.

Kurniawan, N. P., M. Fauzi, Pujdiadi, Masudah, D. Sulastini, \& R. Suryaningsih. 2003. (in Indonesian). Information Book of the Alas Purwo National Park. Alas Purwo Nasional Park Centre. Banyu Wangi, East Java.

Kurniawan, N. P \& S. Ponihadi. 2004. (in Indonesian). The Experiences and Ecotourism Prospect Based on Sea Turtie and Environment. Presented in Seminar the Development Strengthened of Sea Turtle Ecotourism as Utilization Alternatives of Extractive Sea Turtle. WWF-Indonesia. Denpasar. $26^{\text {th }}-27^{\text {th }}$ February 2004

Nuitja, I. N. S. 1996. (in Indonesian). Conservation and Development of Sea Turtle in Indonesia. Workshop of the Research and Management of Sea Turtle in Indonesia. Proceeding. Jember. November 1996.

Nontji, A. 1987. (in Indonesian). The Nusantara Sea. Djambatan Publisher. Jakarta. 368 pp.

Septiastini, W., D. Astanafa, Ngadiwang, B. S. Purbowo, \& Andriyanto. 2000. (in Indonesian). Green Turtle. The Potential of Flora and Fauna in Merubetiri National Park. Edition I. Jember. 11 pp.

Sulaiman, P. S. 2004. (in Indonesian, Unpublished). Study on the Captivity Breeding and Conservation of Sea Turtles in Ngagelan Beach Alas Purwo National Park District of Banyuwangi East Java Province. Thesis in Fisheries Faculty Brawijaya University, Malang. 102 pp.

Wiadnyana, N. N. \& A. Fitriyanto, 2009. In Preparation. 
